$$
\text { CONF- } 940815--119
$$

\title{
DEVELOPMENT OF AN EXPERT SYSTEM FOR TRANSPORTATION OF HAZARDOUS AND RADIOACTIVE MATERIALS
}

\author{
J. J. Ferrada \\ R. D. Michelhaugh \\ R. R. Rawl \\ Oak Ridge National Laboratory* \\ Oak Ridge, Tennessee 37831-6495
}

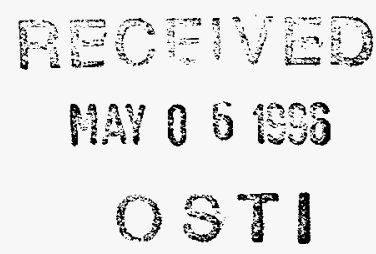

For presentation and publication at the "Spectrum '94: International Nuclear and Hazardous Waste Management meeting in Atlanta, Georgia

August 14 - 18, 1994

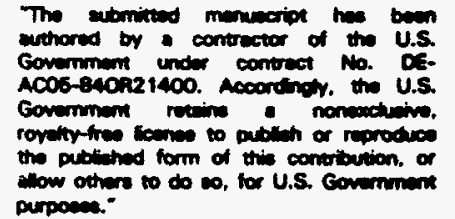

*Managed by Martin Marietta Energy Systems, Inc., for the U. S. Department of Energy under contract DE-AC05-84OR21400.

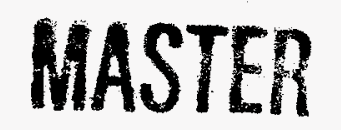

i:

DISTDIBUTION OF THIS DOCUMENT IS UNLIMITED 


\section{DEVELOPMENT OF AN EXPERT SYSTEM FOR TRANSPORTATION OF HAZARDOUS AND RADIOACTTVE MATERIALS}

\author{
J. J. Ferradia \\ Uak Ridge National Laboratory* \\ P. O. Box 2008, MS.6495 \\ Oak Ridge. Tennessec 37831 \\ (615) $574-4998$
}

\author{
R. D. Michelhaugh \\ Oak Ridge National Laboratory* \\ P. O. Box 2008, MS-6495 \\ Oak Ridge, Tcracssce 3783! \\ (615) 574-6819
}

\author{
R. R. Rawi \\ Oak Ridge National Laboratory • \\ P. O. Box 2008, MS-6495 \\ Oak Ridge. Tennessec 37831 \\ (615) 574.4713
}

\section{INTRODUCTION}

Under the sponsorship of the U.S. Deparument of Excrgy's (DOE's) Transportation Maragenamen Division (EM-261), the Trensportation Technologies Group at Oak Ridge National Laboratory (ORNL), has decigned and developed an expert system prototype application of the hazardous materiais transportation regulations. The abjective of this task was to provide a proof-of-concept for developing a computerized expert system that will ensure straightorward, consistent, and error-free application of the hazardous materials transportation regulations. The expert system prototype entuiled the analysis of what an expert in hazardous materials shipping information could/should do.

From the aralyais of the different fectures required for the expert systern prototype, it was concluded that the developmental efforts should be directed to a Windows ${ }^{\text {Th }}$ 3.1 hypermedia environment. IIypermedia technology usually works as an interactive software system that gives personal computer users the ability to organize, mannge. and present information in a number of formats-lext. graphics, sound, and fill-motion video.

\section{DEVELOPMENT}

The strategy to develop the expert system was to fissh, demonstrate the teasibility of developing an expert system prototype by developing modules to capture the knowledge of different areas of tranaportation and packaping; second, select an appropriate environment in which to deploy the expert system; third, andyze the feasibility of appending these different modules in one final full package; and fourth. deveiop the full-scaic expert system.

\section{A. Rediouctive Material Prototype Development}

The initial protatype to demonatrate the teasibility of developing the expert system was based on a module for transporting and packaging radioactive material. Later, a module that includat hazardoun chemicals was developed.

The feagibility stage included (1) anulysis of commercial software related to regulation access, (2) knowledige nequisition, and (3) development of the expert systexn prototype. The strategy to develop the latter subtakik was to (a) develop modules to capnure the knowledge of different areas of transportution and packaping and (b) andyze the feasibility of appending these differeat modules as one final full program. Two individual modules are usod, one for transporting and packaging of radianctive materials and another for transporting and packaging hazardous chemical materials. The final product will integrate these two matuies into an overall hazardous and redioactive materials system.

1. Analytu of commencial programs. The andysis of the commercially available software, RegScanTM and Environmental/Safety Librarytm, indicated that both packages, although very useful for navigating the pertinent regulations, are not particularly suitable for the detemination of the type of packsging required for hazardous and radioactive material transpontation; additional logic is needed. However, the regulations could be downlonded from these software systems and used as the source data base for the regulations that will be accessed by the expert systen.

- Managed by Martin Marietta Energy Systerns, Inc. for the U.S. Department of Energy under contract DE-AC05-840R21400. 
2. Knomiadge acquintition. The development of an expert systen in any developmental stage requures a close rehationship between the developer and the subject expert. Accordingly, the knowiedge muen luw from the expert to the developert in a manner such that the latter can visualize the "branches and trunk" of the required knowledge "tree." Typically, the initisl prototype is concenad with oniy a particular portion of the problem and does not provide the full range of ultimate solutions.

The U.S. Department of Transportation (DOT). the Nuclear Regulatory Commission (NRC), and the Environmental Protection Agency (EPA) have stringent regulations regarding the packaging of hazardous materials before these materials are shipped For exanple, the DOT regulations specify types of packages (c.g. stecl drum, plastic-lined wooden box, etc.) in which each hezardous material may be shipped; the shipper decides which one to use. However, sclecting ane of the allowed packages is not simple task. To dethicve this goal. the shipper must sift through hundrods of regulations, search largo tables, and perform calculations, depending on the applicable regulations. Compounding this problem is the fact that the DOT and EPA require specific chernical names to identify the material being shipped.

Work has been dane 23.4 to incaporate the transportation packaging knowledge base for radioective materials into a logic diagam. This logic diagram Iepresents the decision-making process that the use follows when evaluating the transport of radiosctive materiais. Anticipated IAM-169A' regulatory changes hnve been included in the prototype; this effort required some changes to the original logic diagram. The logic disgram for radioactive materials transportition packaging is represented in Fig 1, which reprewents the global logic diagram and illustretes the fve diffenent stages necessary to detwmine the type of packaring required for transporting a given radioactive material. Stage I of the logic diagram simpiy representa the data isput required from the user. At this point, the vaer mus answer if the material conforms with the definition of radiosctive material. In addition, the user aecds to apply information about the isotopes that comprise the radiantive material [i.e., how much activity per isotope. the form of the material (special or normal), and the physical state of the material (solid, liquid, or gas)]. Along with this information, stage 1 of the diagram contains coungh data for the program to calculate the fraction of $A_{1}$ (if material is special form) or the fraction of $A_{\text {, }}$ (if materisl is normal form). Decisions will be based on the value of this fraction and will determine the path for the following stages of the logic diagram.

Stage 2 of the logio diagran datermines whothe the material to be transported is fissile, nonfissile, or fiscile exempted. Stage 3 of the logic diagram determines if the material qualifies as limited quantity. Stage 4 determines, for a given material that bas not qualifed as limiled quantity and has been deciared as normal form. whether the muterial ean be shipped as low specific setivity (LSA) ot sufhoe-contaninated object (SCO). Once the system has determined that the total activity is los than $2 A_{1}$ (as specified on page 47458 of Ref. 5), the uer is in a position to answer whether the materivi could be shipped as LSA or SCO. Stage 5 of the logic diegram determines the type of pacicage recommended for tramspurtetion of the radionotive material. Obvioualy, this generalized logic disgram illustrates only the concept behind each stage of the search Each stage has its own intricate logic diagram to deternine spacific tagice.

3. Development of the prototyme. The preliminiry progesur to support the proaf-of-concept process was developed using Prolog (Programming in Logic). This preliminary stage helped to docide that it was possible to develop such a program. At the same tine his preliminary protoype was an aid in recognizing the basic requirements for development and the required fenires of the progrem. The goal of the proof-of-concept stage was to socure funding for a proposel that would allow the development of a more sthuchured and arganized expert system. Details about this program are not convidered to be crucial for the development of the final expert system and will aot be presented here.

The basic requirmments of the prototype development were that the expert system would nin on the personal computer (PC) platform. It wes olear that one requirement of the expert system is the ability to acens the regulations from the commencial prograns that update the reguiations on regular basis. The friendliness of the use inerface was another irmportent requirentent togther with the ability to navigate throughout the regulations and display graphics and full-motion vidion information on the screen. The first concern of the knowiladge cagines was to develop an interface between the use and all the specific program(s) that was trangarent regendiog the rmanipulations that are required to 80 from (a) one set of inpuc date, to (b) calculation programs, to (c) decision-rnaker programs, etc. Thus, a strightforward vystem of a question-answer relationship benven the computer and the user was highly desirable. Above all, the prograra had to provide an environment 


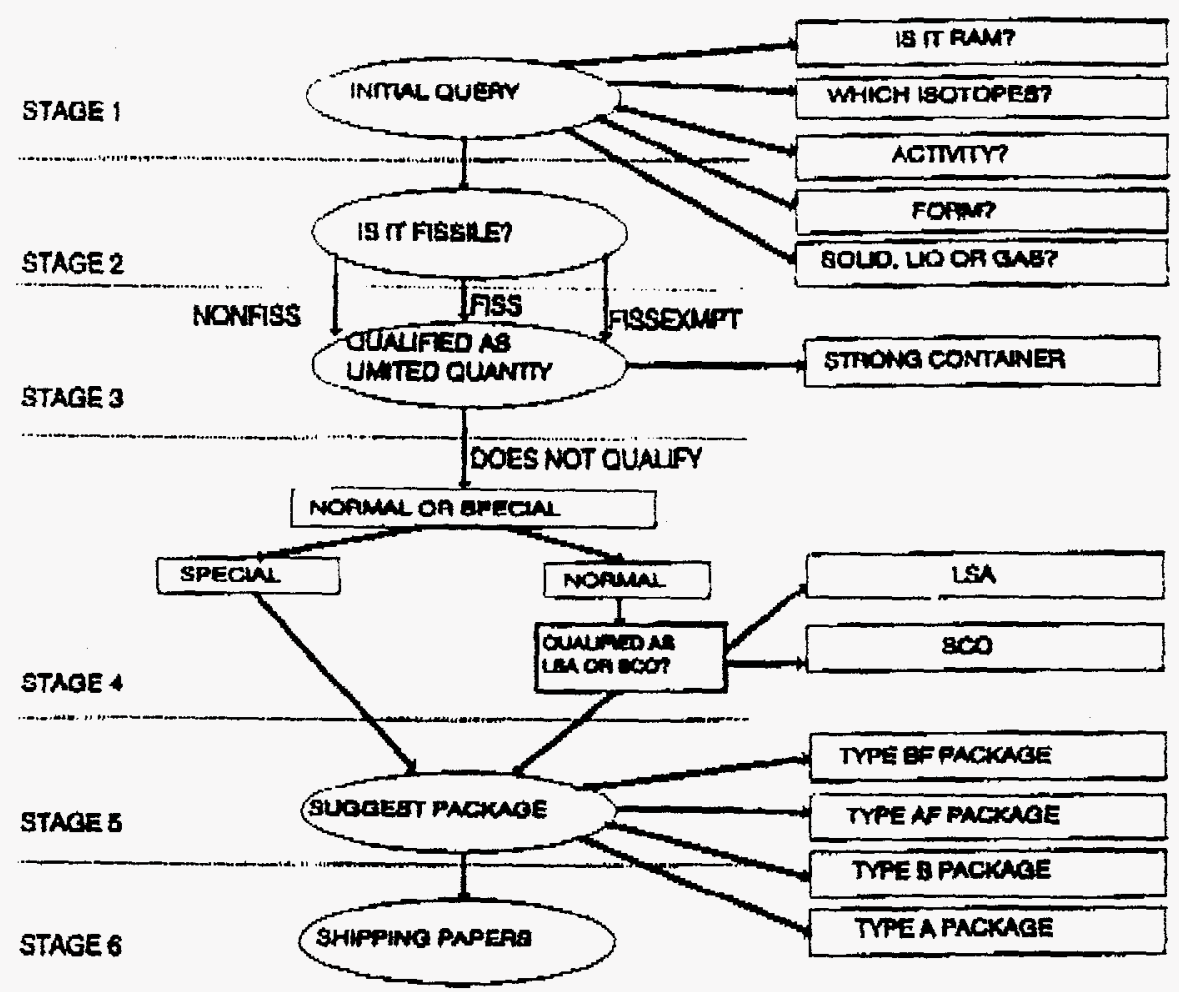

Fip. 1. Radiouctive logic diagram.

wherein a rule-based system that represents the application of regulations can be implenented

Other requirenents, inciuding scoess to several types of information sources, were suggested by the logic diagram. Behind every question asked of the user, there is a set of reguintory requirement(s) which may influence the answer given by the user. Thus, it was obvious that the user had to access the regulations in some casea before an answer could bo giveo to the quexion. This feature provides the less knowledgeable user foough information to give an appropriate response. It is wellknown that reguiations noroully refer to other regulations or parts of regulations, which in turn moy refer to ober regulations and so on. In such complex cress, the expert system not ondy needs to access regulations, but also it must be able to browse through them. Additional explanations about regulations, interpretation of regulations, or any other aspeet of the decision mechanism to detomine types of packages were required to be available in a form of video images or audio help. Consequently, multimedia elements such as text navigaticn, visal aids (whether as graphic or full-motion form), and mouse-driven interface elements were comidered to be ascarial parts of the expent syatem.

To decide what software tool would be used to create the expert system prototype, five possible tools uring five criteria were ratod. These criteria were multimedia capabilities, rule-making capabilities, Dexibility of the environment, user interface provided by each tool, data-kandling capabilities of each tool, and cere of use of each tool. The following tools were rated: $\mathrm{OWL}^{\mathrm{TM}}$ Industries Guide ${ }^{\mathrm{TM}}$ (a multimedia document presenter), the $\mathrm{ClCH}$ progroming languge (a general programming languse), the Prolog programming language (a logic-based disk operating system (DOS) programing language], general expert system shells (tools used to creats expert systems), and the Visual 
Basic ${ }^{\text {M }}$ programming language (a general Windows programming language).

Ratings on these criteria suggested that Visual Basic was the best enviroument in which to create the expert system. Althouph a Prolog-based code had already been crented during the proof-of-concept stage, and it was clear that puning the Prolog version togeth required littlo additional etfort, mulimedia foanurea were difficult to obtain using only Prolog. Consequently, this option was abandomed. The solution found for the prototyping stage was to translate the Prolog code into Visual Basic code, which is a Windows application.

The prototype expert system that involves packaging of radionctive materials has been subjected to a review and validation process by expers in the mattor. The logic of the system has been considered to be carrect. Minor changes have been suggested: The program has been revised, and impiementation of this module within the complete system has been undertaken. The denconstration of developing the expert system prototype has produced interesting resuits. It is postible to represent knowledge sbout radioactive material transportation packaging using a logic diagram that has been transiated into a nule-based system. The mechamisan to acess updeted regulatory information from RegScantm, a commercial program, has proven to be technically feasible and within the purview of the license agrecment.

\section{B. Hexardous Materials Module Development}

The feasibility analysis of the hazandous materials module prototype is the next step in developing a global expert system to determine packages to transport radioactive and hazardous materiais. After this, the consolidation of both undules comes out naturally.

I. Development of buardous chemicals expert syatem prototype. The regulations conceraing the transportation of bezardous materisls are contsined primarily in CFR 49 Parts $100-180$. This is two volume set of over 1,100 pages. With such a mass of regulations to formulate into logic that could be programrned into a computer, the regulations were divided into pices. Fortunately, the regulators have divided them into subparts that generally follow a logical gouping of the topics which thoy reguiate. For eximple, the regulations that pertain to shipping papess are primarily in Subpart C; marking, in Subpart D; eto. Esch of these subparts refer back to Subpart $B$, which is the hazardous material table (HMT). Therefore, the comerstone of the reguiations is the HMT. For this Phaso- I proaf-of-concept suxty, the primary focus wes on determining the bozard cless, the proper shipping name (PSN), and the authorized packaging.

The fust step in determining the correct type of package is to detemine the hezard class and the PSN for the material to be shipped. The materials that are regulated by DOT can be brokea into two groups: those that are specifically listod in the HMT and those that are not specificaily listed. For many hazardous chemicals. DOT hes already detrmined the hazard class and given the chenical name as the PSN. For materials not specifically listed. DOT lesves it up to the sthipper to docrumo which hemed clasa(es) the material meets and then to essien the most appropriate PSN according to rules in the regulations. The possible PSN's from the HMT wete grousped as follows in descending order of priority of ust:

1. Specific chemical names including mixtures and solutions of these chemicals. Examples: acetone, methonol, carbon dissulfide. sodium cyaride

2. General chemical names. Examples: nitrates, cctnnes, acid, liquid thallium sait, solid

3. Functional descriptions Exaroples: disinfectunts, disparant ges, cleaning solution, accumulators, adhesive, pesticide

4. General hazand class destriptions, n.o.s. Examples: flummable liquid, corroxive. poison

5. Environmentally hazardous substance, n.o.s. Examples: hazardous substance and reportable quantity (RQ), twarine pollutant

6. Hezondous waste, n.a.s. Exaruples: EPA waste D008. EPA waste F006

7. Not regulated in transport.

The basis for these groupings and onder of goups is derived from 49 CFR Part 172.101. Priority is in the order shown; namely, if a specifie chemical name applien, it must be used when all specific limitations are met. For the chenicals that are specifically listed, the hazard class and packing group have aireaty been detmined by DOT.

If the chemical is not specifically listed, then information about the characteristics of the material must be known in order to classify the material before the PSN can be determined. In these cases, both the hanard class(ea) and packing group(s) may need to be dotermined for proper elsurification. After the hazard class(es) and pecking group(s) are detemined, the gencral chemical group is checked to determine if the 
material qualifies as any of these PSNs. If not then the finctionil-descriptions group is checked to see if the function of the material is listed. If the material does not fit any of the previous PSNs, then the approprive choico from the geveral hazand class, n.0.3. is selected. If the material does not meet the definition of any of the DOT hazard cinses it still might be regulated as indicated by its appearing in the HMT appendixes. Finally, if the material is classified as an EPA waste but doen't meet the definition of any DOT hazard class or hazandows substance, then the PSN of hazardous waste, a.o.8. is selected.

Once a PSN is selected, the hazard class and packing groxp are checked to see that the material moets that PSN's assigned bazard class and packing group. If it does not, that PSN may not be used. This ahesk is not needed for technically pure chemicals, but it is very important for mixtures and solutions, generd chemical descriptions, and functional descriptions becsuse the charactaristics may have changed substantially from the pure chemical.

The conversion of the regulations to computer logic will be explaind in the following paragraphs. Figure 2 ropresents the first stage of the logic diagram in which certain information about the shipwent is needed throughout the system. The information defines which sections of the rogulations are applicable to the shipment For ingtemoe, if "nonbulk" is chosen, the system igores the regulations that pertain only to bulk shipmats. If "alrcraft" is selected, then regulations for highway, rail, and water will be skipped (It is recognized that mulimodal shipments need to be included in the scope of the final expert system.

The sand stage of the logic diagran deals with hazardous substances. The DOT also regulates herardoess substanos (listed in sppendix $A$ to the HMT). This list is deremined by the EPA. The Table of Marine Pollutantare also evaluated to determine if a matrial is also a marine pollutant. The third stage of the logic diagram determines the PSN, hazerd clase, and packing group uxing the approach described previously. All materials that meet the definition of a DOT hazserd class will be acrigned a name from hare. Most materials that get past this section will either be unutgulated or be a hazardous substance or hazardous warte which are regulated.

The fourth stago of the lopic diagram deals wilh modes of transportation. Some materials are regulated only when they are transported by certain modes. If the trappart made selected is pot a regulated mode, then the material is not regulated. Som PSNs are restricted to either domestic or intemational use. The logic in the middlo of the diagram checks for such restrictions. The other stage of the logic diagram determines the authorized peckaging for the shipment inciuding the special provisions applicsble to the shipment

\section{Appendiag Diterent Modules}

The two prototype modules have been finalized and have incuportied the mortise for the transportation and packaging of radiosctive and hazardous materials. Both modules can work separately, but from a practical point of view, the user would like to have them both togethar and be completely interactive. The system developed here promises to help transportation management not only with routine daily packaging duties but also, and more importantly, with those unusend cases requiring more regailatory information to stay is compliance.

\section{VERIFICATION AND VALIDATION}

The verification of the hazardous materials expert system (HaMTES) bas been performed in two phuses. In the first phese. the lopic model was evaluated aguinst the reguitions by at leant throe experts. Then it was manully demonstrated that the model correctly performs the pectaging-ellection fincticas by comparing the operation of the HaMTES system with known shipments and packages. Model validution can be performed by a trained and an experienced traftic specialist using 49 CFR. Verification of the HaMTES system, the second phese of this ectivity, will test whether the system accirately represents the model.

The document that will be entered as the quality record includes the (I) verification plan, (2) verification reparts, (3) logic diagram and hand determinations for the various certs, (4) exampies used to verify the model, and (5) HaMTES users' manual.

\section{rv. CONCLUSION}

As previously mentioned the DOT regulations determine the correct peckaging for the transportation of hererdous materials. The logic involved in determining the correct peckuge for a shipment has been succesiully implementod as a docision tree, using the Revised Radioactive Materials Transportation Regulations as 
ORNL DWOF 948636

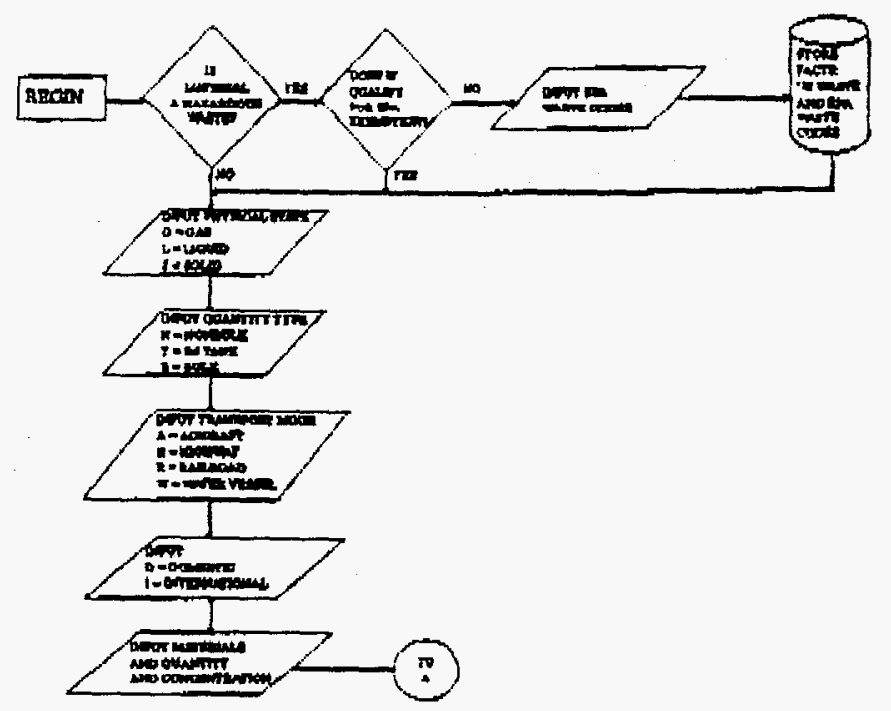

Fig. 2. Chemalcal hezardous material logic diagram.

proposed in HM-169A. This work was perforwed in anticipation of the publication of the Final Rule HM169A this year.

Somo changes may heve to be rands when the Final Rule is published, but these changes are expocted to be minor. Because HM-169A has not been finmlized, this system cannor be used for actual shipments. There are substantial differexces between the current regulation and the HM-169A proposed regulations; these differences could result in incorrect packaging if this system were used to prepare a shipment before HM-169A is finalized.

The development of both prototypes produced positive results in that it was concluded that the pertinent regulations can be tranelated into a logic dingram and that this logic diagram en be trantated into a computer code. In addition, it was concluded that for presentation purposes, better merocty utilization, and a larger portfolio of computer fearurea, it was best to develop the hazardous materials modules completely in Windows 3.1 . The language selected for developing the user interfuce and the rulc-based system was Visual Basic.

A quality assurence plan has been deveioped and inglentented for the validation and verification of the expert systems The purpose of this verification plan is 10 establish specific responsibilities and methods for the validation and verification of the HaMTES in arder to do quality work to support of the DOE Transportation Manasement Division (EM-261).

\section{REFERENCES}

1. J. J Ferradn, J. M. Holnes, -Developing Expert Systems", Chemical Engineering Progress, (April 1990).

2. A. Tarmuzzer. persond communication to R. R. Rawl, Oak Ridge National Laboratory, Oak Ridge, Tainessex, October 1991.

3. R. Micholhaugh, Portsmouth Guseous Diffusion Plent personed cornmunication to IJ J. Ferredia, Oak Ridge National Laboratory, Oak Ridga, Tennessec, February 1992.

4. J. J. Ferrads V. M. Greer and R. R. Rawl, Teasibility Study-Computeried Application of the Hezardous Materisl Regulations." ORNL/TM-12141, Oak Ridgo Nationel Leboratory, OAk Ridge, Temessee, September, 1992.

5. HM-169A, Federal Register, Vol. 54, No. 218, p. 47454, Novennber. 1987. 


\section{DISCLAIMER}

This report was prepared as an account of work sponsored by an agency of the United States Government. Neither the United States Government nor any agency thereof, nor any of their employees, makes any warranty, express or implied, or assumes any legal liability or responsibility for the accuracy, completeness, or usefulness of any information, apparatus, product, or process disclosed, or represents that its use would not infringe privately owned rights. Reference herein to any specific commercial product, process, or service by trade name, trademark, manufacturer, or otherwise does not necessarily constitute or imply its endorsement, recommendation, or favoring by the United States Government or any agency thereof. The views and opinions of authors expressed herein do not necessarily state or reflect those of the United States Government or any agency thereof. 